\title{
Erratum to: Editorial: 2016 in Review
}

Fred R. Volkmar ${ }^{1}$

Published online: 27 April 2017

(C) Springer Science+Business Media New York 2017

Erratum to: J Autism Dev Disord (2017) 47:525-534

DOI 10.1007/s10803-017-3077-5

In the published version, the reviewer's name Stephen M. Kanne was misspelled as Stephenn Kane. This is corrected with this erratum.

The online version of the original article can be found under doi:10.1007/s 10803-017-3077-5.

Fred R. Volkmar

lori.klein@yale.edu

1 Yale University School of Medicine, New Haven, CT, USA 